\title{
LONG-TERM RESPONSES OF THE KUPARUK RIVER ECOSYSTEM TO PHOSPHORUS FERTILIZATION
}

\author{
K. Slavik, ${ }^{1}$ B. J. Peterson,${ }^{2}$ L. A. Deegan, ${ }^{2}$ W. B. Bowden, ${ }^{3}$ A. E. Hershey, ${ }^{4}$ and J. E. Hobbie ${ }^{2}$ \\ ${ }^{1}$ University of Michigan Biological Station, Ann Arbor, Michigan 48109-1090 USA \\ ${ }^{2}$ The Ecosystems Center, Marine Biological Laboratory, Woods Hole, Massachusetts 48104 USA \\ ${ }^{3}$ School of Natural Resources, University of Vermont, Burlington, Vermont 05405 USA \\ ${ }^{4}$ Department of Biology, University of North Carolina, Greensboro, North Carolina 27402 USA
}

\begin{abstract}
A long-term stream fertilization experiment was performed to evaluate the potential eutrophication of an arctic stream ecosystem. During 16 years of summer phosphorus $\left(\mathrm{H}_{3} \mathrm{PO}_{4}\right)$ fertilization, we observed a dramatic change in the community structure of the Kuparuk River on the North Slope of Alaska. A positive response to fertilization was observed at all trophic levels with increases in epilithic algal stocks, some insect densities, and fish growth rates. After approximately eight years of P fertilization, bryophytes (mosses) replaced epilithic diatoms as the dominant primary producers in the $\mathrm{Ku}$ paruk River. The moss impacted $\mathrm{NH}_{4}{ }^{+}$uptake rates, benthic gross primary production, habitat structure, and insect abundance and species composition. This study documents the long-term changes in an arctic tundra stream in response to nutrient enrichment. Predicting stream ecosystem responses to chronic perturbation requires long-term observation and experiments.
\end{abstract}

Key words: arctic stream; bryophytes; community structure; ecosystem response; grayling; insects; Kuparuk River, Alaska (USA); nutrient enrichment; phosphorus fertilization; stream fertilization.

\section{INTRODUCTION}

Eutrophication can substantially alter the structure and function of freshwater ecosystems (Smith et al. 1999). Increases in nutrient loading to arctic ecosystems may occur through disturbance in the watershed or changes in regional climate. In the Arctic, an increase in local human activities, such as those associated with oil drilling and road building, will likely lead to a direct increase in nutrient loading of oligotrophic arctic watersheds. Global climate models predict global warming, and it is likely that the effects of these climate changes will not only be recognized first, but also amplified, in the Arctic (Lachenbruch and Marshall 1986, Abelson 1989, Chapman and Walsh 1993). Chapin et al. (1995) and Nadelhoffer et al. (1992) suggest that arctic tundra warming will cause the permafrost to thaw and increase the depth of the active soil layer, leading to an increase in organic matter turnover rates and nutrient availability to tundra ecosystems. The deeper thaw layer and extended thaw season will increase nutrient availability, expose mineral soil, and increase subsurface drainage leading to an increase in nutrient loading to streams (Kane et al. 1992, Woo et al. 1992, Rouse et al. 1997, Hobbie et al. 1999).

We used long-term monitoring and whole-stream nutrient enrichment experiments to understand the impacts of a changing climate and the potential impacts of eutrophication, as well as to discern patterns of nat-

Manuscript received 6 May 2002; revised 3 July 2003; accepted 14 July 2003; final version received 14 August 2003. Corresponding Editor: B. Downes. ural variation in arctic streams. The Kuparuk River, an arctic tundra stream, has been experimentally enriched with phosphorus every summer since 1983 as a part of the Toolik Lake Long-Term Ecological Research (LTER) project. After the first four years of fertilization, algal biomass and productivity increased dramatically, leading to increased growth rates and densities of some insect species and young-of-the-year (age-0) and adult fish (Peterson et al. 1985, 1993a, $b$, Deegan and Peterson 1992). In this paper we extend these results and examine how the river has changed since the fertilization began in 1983. We observed a dramatic change in community structure of the $\mathrm{Ku}$ paruk River during the 16-year phosphorus fertilization.

\section{Methods}

\section{Site description}

The Kuparuk River originates in the foothills of Alaska's Brooks Range and flows north-northeast to the Arctic Ocean, draining an area of $8107 \mathrm{~km}^{2}$. It is classified as a clear-water tundra river (Craig and McCart 1975) because it has no input from glaciers and little input from springs. Our 5-km study reach straddles the Dalton Highway $\left(68^{\circ} 38^{\prime} \mathrm{N}, 149^{\circ} 24^{\prime} \mathrm{W}\right)$, where the Kuparuk is a meandering, fourth-order stream (Fig. 1) draining an area of $143 \mathrm{~km}^{2}$ of alpine and moist tundra communities. Dwarf birch and willows line sections of the stream bank but do not shade the channel. Within our study reach, the river channel has a mean width of $\sim 17 \mathrm{~m}$ and is characterized by alternating riffles (20-30 $\mathrm{m}$ long and 5-30 cm deep) and pools 


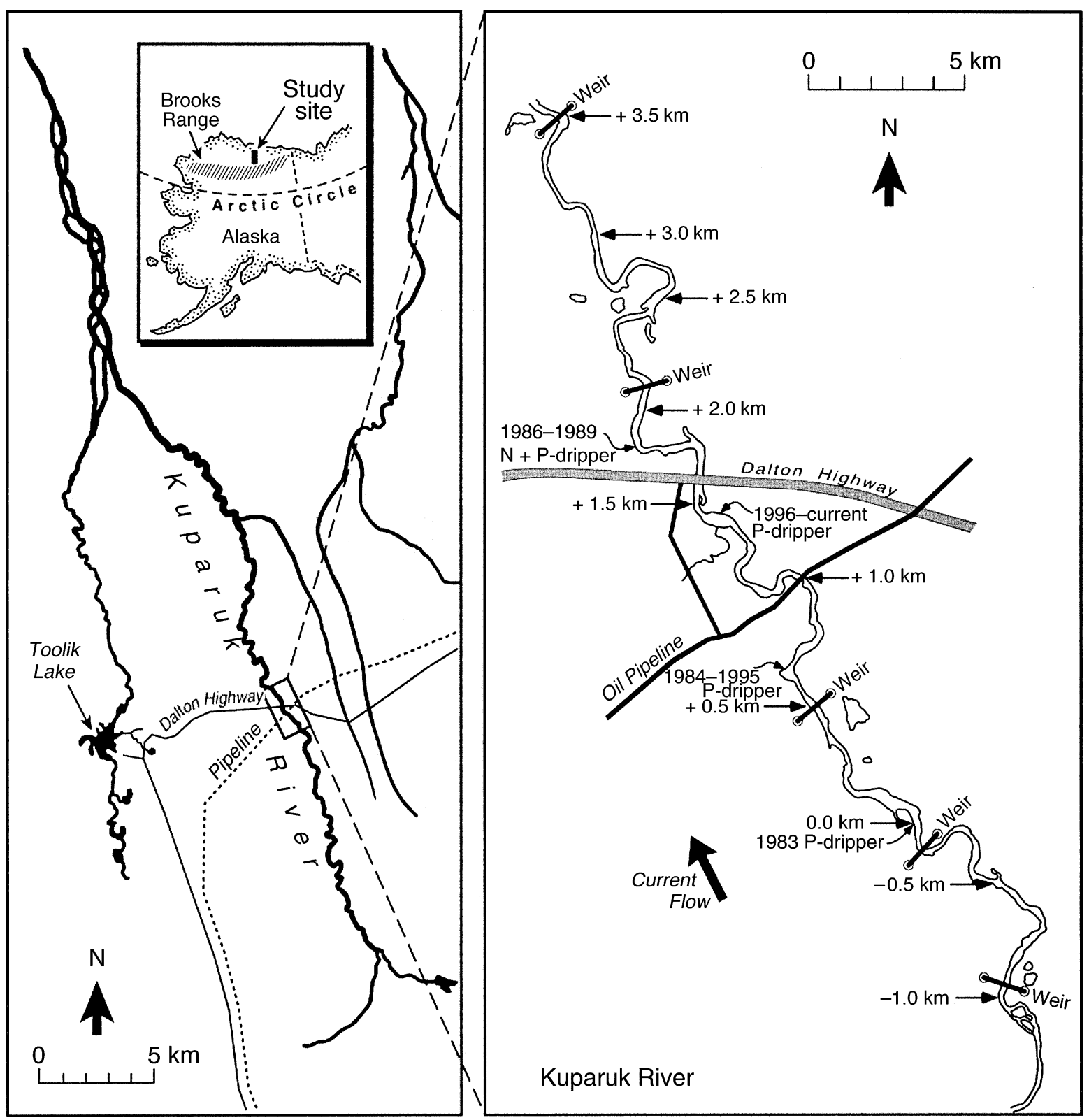

FIG. 1. Map of the fertilization study site, Kuparuk River, on the North Slope of Alaska, USA.

(10-50 $\mathrm{m}$ long and 1-2 $\mathrm{m}$ deep) at the average summer discharge of $2-3 \mathrm{~m}^{3} / \mathrm{s}$. The riffle and pool substrates range from cobbles to boulders. Average channel slope within the study reach is $0.6 \%$. For a more complete description of the Kuparuk watershed, see Kriet et al. (1992) and Hershey et al. (1997).

The river ceases to flow in late September or early October, and pools are frozen solid from October to May; the open-water growing season is approximately four months. Light inputs are high during most of the growing season due to the open canopy and 24-h photoperiod. Summer water temperature in the Kuparuk River averaged $8^{\circ}-13^{\circ} \mathrm{C}$. Maximum precipitation oc- curs in July and August (Kane et al. 1989); however, the peak discharge usually occurs in late May or early June as a result of large volumes of runoff from snowmelt. Mean annual precipitation in the region is $\sim 15-$ $30 \mathrm{~cm} / \mathrm{yr} ; 30-40 \%$ of which falls as snow (McNamara et al. 1997).

The Kuparuk River is oligotrophic and most frequently phosphorus limited (Peterson et al. 1985, $1993 a$ ). Soluble reactive phosphorus (SRP) and ammonium levels are usually near the limits of detection $(0.05 \mu \mathrm{mol} / \mathrm{L})$. Nitrate plus nitrite levels range from 0.1 to $>10 \mu \mathrm{mol} / \mathrm{L}$. Mean conductivity values $(\sim 45$ $\mu \mathrm{S} / \mathrm{cm})$ for the Kuparuk River are typical for tundra 
rivers of the North Slope and are relatively low compared to glacial and spring-fed rivers of this region. Mean $\mathrm{pH}$ is 7.0 , and alkalinity is $\sim 250 \mu \mathrm{eq} / \mathrm{L}$.

Benthic net primary production is low compared to temperate streams, ranging from 15 to $30 \mathrm{~g} \mathrm{C} \cdot \mathrm{m}^{-2} \cdot \mathrm{yr}^{-1}$ (Peterson et al. 1986, Bowden et al. 1992). Allochthonous organic matter input is comparable to temperate, closed-canopy forest streams, but of different composition. Peat from eroding banks is the major source of particulate organic matter loading to the river, $\sim 200-$ $300 \mathrm{~g} \mathrm{C} \cdot \mathrm{m}^{-2} \cdot \mathrm{yr}^{-1}$ (Peterson et al. 1986). Dissolved organic carbon comprises over $90 \%$ of the total organic carbon (mean $\mathrm{TOC}=6.8 \mathrm{mg} \mathrm{C} / \mathrm{L}$ ) export from the watershed (Peterson et al. 1986).

Although bryophytes and filamentous algae are normally present in the upper Kuparuk River, epilithic diatoms dominate the autotrophic community. The dominant diatom species are Hannaea arcus, Cymbella minuta, Achnanthes linearis, Achnanthes minutissima, Synedra ulna, and Tabellaria floculosa (Miller et al. 1992). The macroalgal community consists primarily of Tetraspora, Ulothrix, Stigeoclonium, Batrachospermum, Lemanea, and Phormidium. The dominant bryophyte is the moss Schistidium [Grimmia] agassizii. The mosses Hygrohypnum alpestre, H. ochraceum, Fontinalis neomexicana, and Solenostoma sp. (a liverwort) are also present but are most frequently found in nutrient-rich spring tributaries, and not in the main channel of the study reach.

The benthic invertebrate community is primarily composed of insect larvae. Among the most dominant species are the filter-feeding black flies, Stegopterna mutata and Prosimulium martini, which emerge in midJuly and in early August (Hiltner 1985). Baetis spp. is the dominant grazing mayfly. The mayfly Ephemerella sp. is also present, but far less abundant. There are several species of chironomids present, and the tube builder Orthocladius rivulorum is one of the largest and most abundant (Hershey et al. 1988). Also present is the caddisfly Brachycentrus americanus. This is both a filter feeder and a grazer, and produces at least two cohorts during the summer season (Peterson et al. $1993 a$ ).

Arctic grayling (Thymallus arcticus) is the only fish species found in our study reach. The grayling driftfeed in the river from late June through mid-August, and then migrate upstream to overwinter in headwater lakes. There are $\sim 50-100$ adult grayling ( $>30 \mathrm{~cm}$ total length, Gettel and Deegan 1997) per river kilometer during the summer. Juveniles $(5-25 \mathrm{~cm})$ are present, but in very low abundance $(<10$ individuals $/ \mathrm{km})$. Mean estimates of age- 0 grayling density range from 50 to 100 per pool, and they are seldom found in riffles (Deegan and Peterson 1992).

\section{Stream flow and chemistry}

Stream stage was monitored and then converted to discharge with a stage rating constructed annually from current velocity transects according to the methods presented in Peterson et al. 1992. Temperature was monitored daily with a handheld thermometer (1983-1990) or hourly by a thermocouple attached to a CR-10 datalogger (Campbell Scientific, Logan Utah, USA; 1991-1998).

Water samples for nutrient analyses were collected at $\geq 3$ stations above and $\geq 4$ stations from 0.1 to $4 \mathrm{~km}$ below the P-addition site. Annual mean values were calculated using these weekly measurements (3-7 collection times per year). All water samples were filtered through $0.45-\mu \mathrm{m}$ pore cellulose-acetate filters or precombusted glass-fiber filters with a nominal pore size of $0.7 \mu \mathrm{m}$. Phosphorus (SRP), ammonium, and nitrate plus nitrite were all measured by colorimetric methods, either on an autoanalyzer (Lachat Quik-Chem 8000, Loveland, Colorado, USA and RFA Series 300, Alpkem Corporation, Wilsonville, Oregon, USA) or manually (Murphy and Riley 1962, Solorzano 1969).

Net nitrate and SRP uptake $\left(\mathrm{mmol} \cdot \mathrm{m}^{-2} \cdot \mathrm{d}^{-1}\right)$ by the stream bottom was calculated by the equation, Uptake $=(\Delta[$ nutrient $] \times$ discharge $) /$ streambed area. Annual values were calculated from the mean of 3-7 weekly measurements of net uptake. Uptake was only calculated for the fertilized reach below the P-addition site, where both SRP and nitrate consistently declined. There were no consistent, measurable gradients in the SRP (near detection), ammonium, or nitrate in the reference reach. Lateral seepage inputs of groundwater contributed $<5 \%$ of discharge in either reach and we did not correct for its contribution. Note that these calculations yield estimates of net uptake only and are not equivalent to gross uptake estimated from tracer experiments (Wollheim et al. 2001).

\section{Nutrient additions}

During each summer since 1983, phosphorus (as phosphoric acid) was added to the Kuparuk River via peristaltic pump (LKB 2132 microperpex pump, Amersham Pharmacia Biotech, Piscataway, New Jersey, USA) between 1 July (25 June in 1992-1998) and 15 August to increase SRP levels by $\sim 0.3 \mu \mathrm{mol} / \mathrm{L}(10 \mu \mathrm{g}$ $\mathrm{P} / \mathrm{L}$ ) above ambient. Ambient SRP concentrations were most often at or below our detection limit of 0.01-0.05 $\mu \mathrm{mol} / \mathrm{L}$. During 1983 and 1984, phosphoric acid was delivered by a carboy and siphon with constant head, and the rate of addition was adjusted for changes in daily discharge, according to the methods described by Peterson et al. (1993a). During all subsequent years, the phosphoric acid was added at a constant rate using a solar-powered, peristaltic pump to achieve a final concentration of $0.3 \mu \mathrm{mol} / \mathrm{L} \mathrm{P}$ at a mean summer flow of $2 \mathrm{~m}^{3} / \mathrm{s}$. As a result of adding phosphorus at a constant rate, the fertilizer SRP concentration varied with discharge. Therefore, SRP concentrations near the dripper in the P-fertilized reach were greater than the target level $(0.3 \mu \mathrm{mol} / \mathrm{L} \mathrm{P}$ above ambient $)$ when discharge was lower than $2 \mathrm{~m}^{3} / \mathrm{s}$ and lower than the target level 
when discharge was higher than $2 \mathrm{~m}^{3} / \mathrm{s}$. We compared the mean annual expected SRP concentrations, based on the $\mathrm{P}$ added to the river, with mean annual SRP concentrations we actually measured (minus the ambient reference concentrations) within the first km below the P-addition site. The expected SRP concentrations were calculated from $\mathrm{P}$-addition rate ( $\mathrm{mol} / \mathrm{day}$ ) and mean daily discharge.

In 1986 and 1989, ammonium sulfate $\left(\mathrm{NH}_{3} \mathrm{SO}_{4}-\mathrm{N}\right)$ was added to the Kuparuk River along with phosphorus (Peterson et al. 1993a). The results presented here are based on measurements taken only from the phosphorus-fertilized reach (above the $\mathrm{N}$-addition site of 1986 and 1989) and reflect only the response to phosphorus. The exceptions to this are the fish growth and insect density estimates, because these measurements were taken over the entire fertilized reach including the nitrogen addition reach in 1986 and 1989.

\section{Primary producers}

Beginning in 1992, percentage of benthic coverage of bryophytes, macroalgae, and diatom-dominated epilithic communities was estimated using a point transect method described by Bowden et al. (1994).

Primary production of algal epilithon or bryophyte assemblages were estimated by changes in dissolved oxygen concentrations within recirculating metabolic chambers, according to the methods of Bowden et al. (1992).

Epilithic chlorophyll as an indicator of algal biomass was estimated at least twice during each summer's fertilization period (July and August), at $\geq 3$ stations above and $\geq 4$ stations from 0.1 to $4 \mathrm{~km}$ below the Paddition site. Exceptions include 1987, when epilithon was not sampled in July, and 1994, when epilithon was only sampled in August. In 1988, filamentous green algae were abundant in the fertilized reach. Using our normal protocol, it was impossible to avoid the contamination of the micro-epilithic chlorophyll samples with green algal holdfasts and filaments. Therefore, the chlorophyll estimates for 1988 represent the sum of micro-epilithon and filamentous algae.

Two different methods were used to obtain epilithic chlorophyll. From 1983 to 1987, epilithic material was scrubbed with a steel brush from the entire surface of rocks sufficient to cover the bottom of a dishpan of a known area and then rinsed into a known volume of stream water (Peterson et al. 1993a). This was repeated three times at each sampling site. From 1988 to 1998, a known area on the upper surface of a rock was scrubbed with a steel brush to remove the diatom-dominated epilithon and rinsed into a known volume of stream water. This procedure was repeated for five randomly selected rocks within the same riffle, avoiding rocks covered with bryophytes or filamentous algae. Epilithic chlorophyll estimates made using the two methods simultaneously (over a four-year period) were found to be statistically the same (paired $t$ test, $P=$
$0.3, n=36)$ in all treatments and during flows $>0.8$ $\mathrm{m}^{3} / \mathrm{s}$ (mean discharge for the two weeks prior to epilithic sampling). However, the chlorophyll estimates tended to be $\sim 30 \%$ greater using the whole rock scrub procedure under very low $\left(<0.80 \mathrm{~m}^{3} / \mathrm{s}\right)$ flow conditions (paired $t$ test, $P=0.08, n=8$ ).

To estimate epilithic chlorophyll, a subsample of "whole rock" or "upper rock surface" epilithic slurry was filtered onto a glass-fiber filter and then extracted in $\mathrm{MgCO}_{3}$-buffered $90 \%$ acetone in the dark at $4{ }^{\circ} \mathrm{C}$ for 24-48 h (Strickland and Parsons 1968). Total chlorophyll was measured fluorometrically using a Turner Designs 450 fluorometer (Turner Designs, Incorporated, Sunnyvale, California, USA) from 1983 through 1996 and a Turner Designs 10-AU fluorometer in 1997 and 1998.

An homogenized composite of the replicate epilithic slurries at each station (3 or 5, depending on the scrub method) was then subsampled, filtered onto a pre-combusted glass-fiber filter, and dried overnight at $50^{\circ} \mathrm{C}$ for subsequent measurement of total particulate carbon, nitrogen, and phosphorus. Particulate phosphorus (PP) was measured by the acid digestion method of Stainton et al. (1977). Particulate carbon (PC) and nitrogen (PN) were determined by combustion using a Perkin-Elmer model 240C elemental analyzer (Perkin-Elmer, Norwalk, Connecticut, USA). Analyses of mean annual epilithic standing stocks (CNP) and their atomic ratios are based on 2-4 stations per reach sampled twice during each summer's fertilization period.

Epiphytic material was removed from mosses, $H y$ grohypnum spp. and $S$. agassizii, by rinsing and sonication (10 $\mathrm{min})$. The resulting slurry was filtered through a $100-\mu \mathrm{m}$ sieve to remove any moss fragments knocked loose during the sonication. The epiphytes were filtered and analyzed as for epilithic chlorophyll determination. The sonicated moss was then dried at $50^{\circ} \mathrm{C}$ overnight and weighed to determine chlorophyll per gram dry mass of moss. Levels of epiphytic chlorophyll present on mosses were compared with rock epilithic chlorophyll based on percent cover estimates of moss and rock habitats in riffles. These estimates were based on a percent benthic cover and biomass (grams dry mass moss per square meter) relationship developed for the dominant moss species of the $\mathrm{Ku}$ paruk River (Arscott et al. 1998).

\section{Insects}

Benthic insect samples were collected in riffles along river transects three to seven times from late June to early August to estimate density according to the methods described in Peterson et al. $1993 a$ and Hershey and Hiltner 1988. Each transect consisted of four stations upstream and nine stations downstream, and at least two replicate samples were taken from riffles at each station. Each sample was collected by scrubbing the surface of four rocks, with an average upper surface area of $363 \pm 18 \mathrm{~cm}^{2}$, into a plastic basin with a soft 
bristle brush. The sample was concentrated using a 100$\mu \mathrm{m}$ mesh net.

From 1984 through 1992, insects were sampled from bare rock habitat in reference and fertilized riffles. As the substrate available for insect colonization partially changed from bare rock to bryophytes in the fertilized reach in the 1990s, the insects were collected from both bare and moss-covered rocks. The habitat selected for insect collections reflected the shift in dominant benthic cover in the fertilized reach.

\section{Fish}

Young-of-the-year (age-0) arctic grayling growth was estimated by measuring changes in length (TL \pm $0.05 \mathrm{~mm}$ ) and wet mass (TM $\pm 0.001 \mathrm{~g})$ during July and August since 1985. Age- 0 grayling mass at $40 \mathrm{~d}$ post-hatch was estimated for each year using the Gompertz growth equation (Ricker 1979, see Deegan et al. 1999). Adult arctic grayling growth has been monitored since 1986 by mass differences of individually tagged fish at the beginning and end of each growing season (Deegan and Peterson 1992). In most summers, natural densities of adult grayling were confined by weirs $(5-\mathrm{cm}$ mesh) to reference and fertilized $1-\mathrm{km}$ reaches of the river (Deegan et al. 1997).

\section{Statistical analyses}

Dependent variables used in paired $t$ tests and regressions were tested for temporal autocorrelation using the Durbin-Watson statistic (SAS 1987). In all but three instances, tests indicated that the null hypothesis of no autocorrelation could not be rejected (Pindyck and Rubenfeld 1998), and therefore, we proceeded with paired $t$ tests and linear regressions in our analyses. In addition, inequality of variances was found for annual mean chlorophyll using the folded- $F$ statistic (Steele and Torrie 1980) and corrected for by log transformation. All variables were log-transformed to help normalize distributions. Significance for all analyses was accepted at $\alpha=0.05$. There was slight serial correlation present in both the reference and fertilized annual mean gross primary production (GPP) and in the fertilized annual mean adult grayling growth data sets. Thus, no further statistical tests were performed on these data.

\section{Experimental design and interpretation}

The design and interpretation of whole-ecosystem experiments has been problematic because replicate ecosystems are sometimes unavailable or replication is not logistically possible and because pretreatment samples are not always available (Hurlbert 1984, Carpenter 1989, Stewart-Oaten and Bence 2001). These issues are relevant to this study because the experiment included no pretreatment data for the fertilized reach and was not replicated.

In terms of pretreatment differences between reaches, we knew from previous work that primary productivity and respiration in four riffles and in four pools were similar, but that pools and riffle habitats were different and that annual differences were large (Peterson et al. 1986). Because the entire reference and fertilized reach consists of similar pool-riffle geomorphology and since discharge over the reach changes only $\sim 10 \%$ due to seepage and one small tributary, we doubt that there were large pretreatment differences between reaches. This idea is also supported by the fact that we have not observed systematic differences among the multiple stations sampled over 16 years in either the reference reach or the fertilized reach, with the exception that the station farthest downstream from the nutrient dripper exhibited a diminished response to the addition. Furthermore, we moved the nutrient dripper location downstream twice in order to study carryover and recovery effects (W. B. Bowden, unpublished data) and have found that differences between reaches reflect the phosphorus status of the water rather than river location. The slightly higher discharge downstream does result in deeper pools, which might be expected to support larger adult grayling, but during the 16 years of study we found no significant differences in length between fish from the two reaches. Nonetheless, the lack of pretreatment data from the entire experimental reach of the river does limit the statistical power of the experiment as we cannot employ the Before-After, Control-Impact (BACI) approach for sampling and analyzing the study (StewartOaten and Bence 2001).

Because we repeated the first six years of the experiment by fertilizing a slightly smaller tundra stream, Oksrukuyik Creek (Harvey et al. 1998), we have some evidence that the Kuparuk River results are generalizable. Here we used a BACI experimental design. Two years of pretreatment data showed little difference in nutrients, chlorophyll, or insect abundance between reference and pre-fertilization zones. Like the results reported here, fertilization increased productivity at all trophic levels, although details of the responses differed (Harvey et al. 1998). The experiment was terminated before bryophytes might have been able to colonize the stream as they have in the Kuparuk. A third stream was fertilized with inorganic $\mathrm{P}$ and $\mathrm{N}$ during summer 2002. This was a small beaded tundra stream that was partly shaded by willows. We found a large immediate response to fertilization from algae, insects, and decomposers (J. P. Benstead, L. A. Deegan, B. J. Peterson, A. D. Huryn, W. B. Bowden, A. C. Green, K. Suberkropp, K. M. Buzby, and J. A. Vacca, unpublished manuscript). Thus, while we were unable to replicate the long-term fertilization in the Kuparuk, we do have evidence of the responsiveness of other tundra streams to added nutrients.

\section{RESUlts}

\section{Stream flow and temperature}

Water temperatures ranged from mean highs $\geq 13^{\circ} \mathrm{C}$ in July to means $\leq 6^{\circ} \mathrm{C}$ in August. Daily fluctuation in 
water temperature ranged between $1^{\circ}-6^{\circ} \mathrm{C}$ depending on radiation input and precipitation. Mean annual water temperature during the fertilization period ranged from $8^{\circ} \mathrm{C}$ to $10^{\circ} \mathrm{C}$. Extreme low and high temperatures during the fertilization period were $3^{\circ} \mathrm{C}$ and $21^{\circ} \mathrm{C}$. Mean discharge during each summer's fertilization period was highly variable, ranging from $0.3 \mathrm{~m}^{3} / \mathrm{s}$ in 1990 to 4.2 $\mathrm{m}^{3} / \mathrm{s}$ in 1995. Summer discharge hydrographs (Fig. 2) illustrate that there was no typical summer flow regime. The long-term (1983-1998) mean summer daily discharge was $2.3 \mathrm{~m}^{3} / \mathrm{s}$. Storm discharges exceeding 10 $\mathrm{m}^{3} / \mathrm{s}$ occurred in 10 out of the 16 summers of the experiment. Typical summer storm hydrographs rise rapidly within a day or two and return to baseflow within a week after the storm. The summers of 1983, 1990, and 1998 were low flow seasons without major storm events during the P-addition period. The summers of 1992-1995 and 1997 were relatively high flow years; when mean July flows ranged from 3 to $5 \mathrm{~m}^{3} / \mathrm{s}$. The mean flow during from 1983 to 1989 was $2.0 \mathrm{~m}^{3} / \mathrm{s}$, and the mean flow from 1992 to 1997 was $3.0 \mathrm{~m}^{3} / \mathrm{s}$.

\section{Nutrients}

The mean reference reach SRP $( \pm 1 \mathrm{SE})$ concentration for all 16 years of the study was $0.08 \pm 0.01 \mu \mathrm{mol} / \mathrm{L}$. The Kuparuk River is phosphorus limited, and SRP levels are typically near the limit of detection $(0.05$ $\mu \mathrm{mol} / \mathrm{L})$, and there were no measurable differences in ambient (reference reach) concentrations between years or between flow conditions. Phosphorus addition elevated the SRP values downstream of the dripper to readily measurable levels (Fig. 3). The mean annual SRP concentrations measured within $1 \mathrm{~km}$ below the $\mathrm{P}$-addition site were similar to the calculated SRP concentrations we expected based on the $\mathrm{P}$-addition rate and discharge. Both expected and measured SRP levels were above the target value of $0.3 \mu \mathrm{mol} / \mathrm{L}$ in low flow years and below the target in high flow years as expected.

Annual mean reference reach nitrate $\left(\mathrm{NO}_{3}{ }^{-}\right)$levels ranged from 0.4 to $5 \mu \mathrm{mol} / \mathrm{L}$. Nitrate levels were usually lower in the fertilized reach, indicating increased biological uptake in this reach. There was an inverse correlation between annual mean nitrate concentration (ambient) and discharge $\left(r^{2}=0.435, P=0.007, n=\right.$ 15,1987 excluded). On a seasonal basis, nitrate concentrations increased with declining flows in July.

Ammonium $\left(\mathrm{NH}_{4}^{+}\right)$levels in the Kuparuk were usually below our limit of detection $(0.2-0.35 \mu \mathrm{mol} / \mathrm{L})$ of the colorimetric (phenol hypochlorite) method used during the first 16 years of this study.

Nitrate and SRP net uptake rates were typically highest within the first $1.5 \mathrm{~km}$ below the P-addition site. Mean annual SRP uptake (means $\pm 1 \mathrm{SE}$ ) ranged from $0.6 \pm 0.1$ to $1.8 \pm 0.5 \mathrm{mmol} \mathrm{SRP} \cdot \mathrm{m}^{-2} \cdot \mathrm{d}^{-1}$ within $0.2-$ $1.5 \mathrm{~km}$ below the addition site and ranged from $0.2 \pm$ 0.0 to $0.8 \pm 0.1 \mathrm{mmol} \mathrm{SRP} \cdot \mathrm{m}^{-2} \cdot \mathrm{d}^{-1}$ within the $1.5-$ $3-\mathrm{km}$ reach. Nitrate uptake rates ranged from $1.0 \pm 0.2$ to $5.4 \pm 0.3 \mathrm{mmol} \mathrm{NO} \cdot \mathrm{m}^{-2} \cdot \mathrm{d}^{-1}$ within $0.2-1.5 \mathrm{~km}$ below the addition site and then dropped to a range of $0.4 \pm 0.3$ to $1.1 \pm 0.3 \mathrm{mmol} \mathrm{NO} \cdot \mathrm{m}^{-2} \cdot \mathrm{d}^{-1}$, where they approached reference reach uptake rates $(0.1-1.3 \mathrm{mmol}$ $\left.\mathrm{NO}_{3} \cdot \mathrm{m}^{-2} \cdot \mathrm{d}^{-1}\right)$. Note that these are net removal rates (uptake-regeneration) and not gross rates.

Primary producers.-Gross photosynthesis and respiration $\left(\mathrm{mg} \mathrm{O}_{2} \cdot \mathrm{m}^{-2} \cdot \mathrm{h}^{-1}\right)$ of the epilithic biofilm on riffle rocks tended to be greater in the P-fertilized reach than in the reference reach (Fig. 4). Paired $t$ test of respiration rates indicated significant differences between fertilized and reference reaches (June-August $P$ $<0.019, n=11$ ). Similar significant differences existed between the fertilized and reference reach measures of GPP $(P=0.001, n=11)$, but this $P$ value is not exact (unbiased) due to slight serial correlation present in both the reference and fertilized annual mean GPP data sets. There was a steady decline of gross photosynthetic rates for epilithon in the fertilized reach after 1992.

Epilithic chlorophyll levels were consistently higher in the fertilized reach (Fig. 5, paired $t$ test of annual means, $P=0.0015, n=15$ years, 1988 excluded). Like the decline in epilithic GPP and respiration, we observed a decline in epilithic chlorophyll in the fertilized reach in the early 1990s.

Annual mean epilithic standing stocks (micromoles per square centimeter) of carbon, nitrogen, and phosphorus were larger in the fertilized reach than in the reference reach (Table 1). Overall mean atomic C:P and $\mathrm{N}: \mathrm{P}$ ratios of epilithic standing stocks were lower in the $\mathrm{P}$-fertilized reach, and mean atomic $\mathrm{C}: \mathrm{N}$ ratio was $\sim 12$ in both reaches.

Bowden et al. (1994) noted an increase in coverage of bryophytes (specifically Hygrohypnum spp.) in the fertilized reach beginning in 1990 and 1991. Hygrohypnum had not been noted in this reach before 1990 . Schistidium agassizii was present throughout the experimental area at low levels, and anecdotal information suggests that total bryophyte coverage in the fertilized reach was comparable to the coverage in the reference reach. Moss coverage increased rapidly in the fertilized reach during 1990 and 1991, based on measurements of biomass harvested from $0.25-\mathrm{m}^{2}$ quadrats.

Bryophyte coverage in fertilized riffles was over 10 times that of the reference levels in some years (Fig. 6). We attribute this dramatic increase after a lag of approximately eight years to long-term $\mathrm{P}$ fertilization. The observed decline in moss cover when nutrients addition was stopped in one river segment supports this idea (W. B. Bowden, unpublished data). The moss, Hygrohypnum, comprised 75 to $95 \%$ of the bryophyte community within fertilized riffle habitats, forming a continuous carpet over large segments of the stream bottom. The reference reach bryophyte community was almost entirely composed of the moss $S$. agassizii throughout the study. S. agassizii did not appear to 

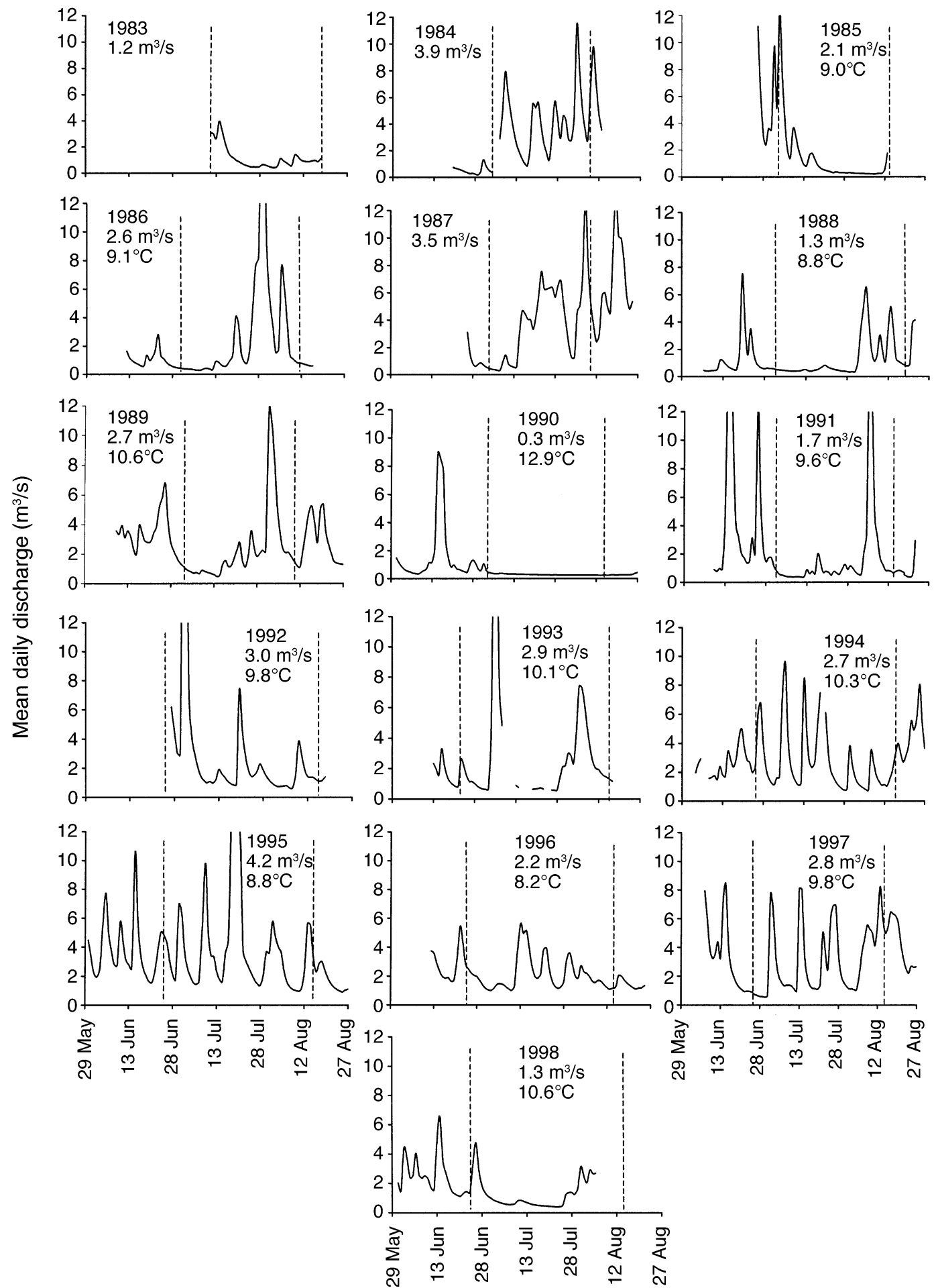

FIG. 2. 1983-1998 Kuparuk River mean daily discharge. Dashed lines mark the beginning and the end of the phosphorusfertilization period. Mean discharge $\left(\mathrm{m}^{3} / \mathrm{s}\right)$ and water temperature $\left({ }^{\circ} \mathrm{C}\right)$ for this period are listed for each year (water temperatures are not available for years 1983, 1984, and 1987). 


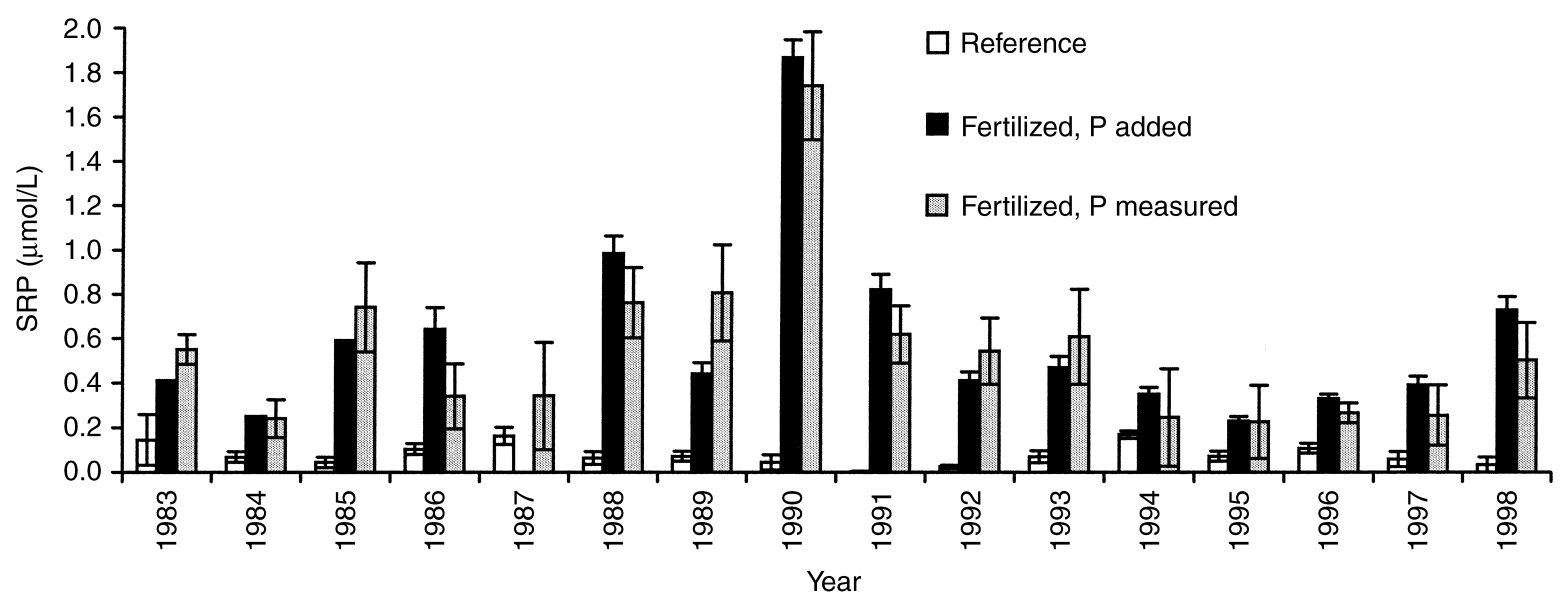

FIG. 3. Soluble reactive phosphorus (SRP) concentrations (mean $\pm 1 \mathrm{SE}$ ) in the reference and fertilized $(0.15-1.0 \mathrm{~km}$ below P-addition site) reach of the Kuparuk River. Reference values are the mean of weekly measurements from $>2$ locations above the P-addition site. In the fertilized reach, "P added" is the average P calculated from addition rate and discharge. "P measured" is the actual mean daily $\mu \mathrm{mol} / \mathrm{L}$ SRP (the ambient reference reach values) measured within the first kilometer below the P-dripper. Fertilized reach values for 1983-1986 are taken from Peterson et al. (1993a). P-addition rate estimates were not available for 1987.

respond to fertilization; mean percent of benthic cover ranged from 3 to $15 \%$ in the reference reach and 0 to $12 \%$ in the fertilized reach during the entire period of observation. Other bryophytes, such as Solenostoma, made up $<1 \%$ cover of the benthic cover in the reference reach and ranged between 0 and $20 \%$ cover in the fertilized reach during the study. A less dominant moss, Fontinalis neomexicana, was not seen in the reference reach, but it comprised $0.5-5 \%$ of mean annual benthic cover in the fertilized reach.
Standing stocks of epiphytic algal chlorophyll attached to the moss Hygrohypnum were much greater than the levels of algal chlorophyll found on S. agassizii or on bare rocks without moss within the same fertilized riffle (Table 2).

\section{Insects}

The response of insects to the fertilization and change in moss cover differed among the dominant taxa (Fig. 7). Throughout the long-term study, Brachycen-

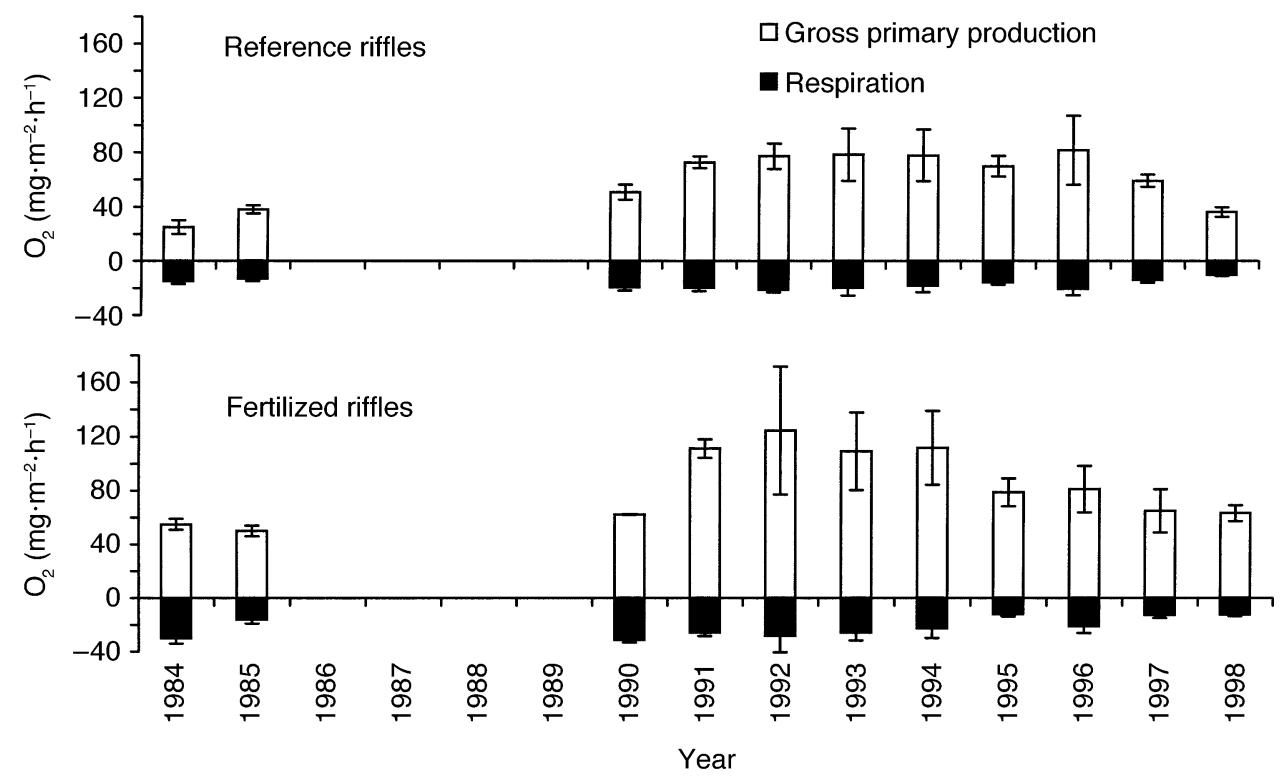

FIG. 4. Gross photosynthesis and respiration rates of riffle epilithon in the reference and P-fertilized reaches of the Kuparuk River. Means ( $\pm 1 \mathrm{SD}$ ) are from late July and early August measurements, during the days of phosphorus fertilization for all years except 1991 (a mid-July measurement). The 1984 and 1985 values are taken from Peterson et al. (1993a). 


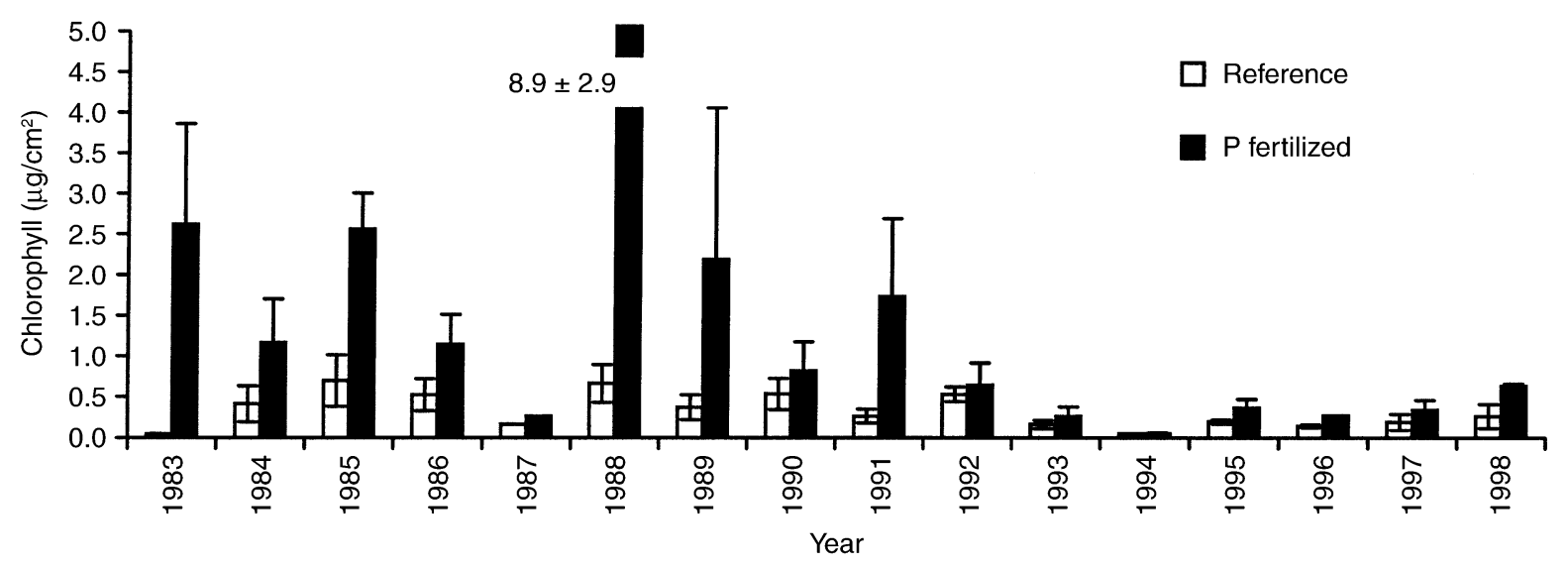

FIG. 5. Epilithic total chlorophyll in the reference and fertilized reach riffles of the Kuparuk River during fertilization (July and August). Values for 1987 and 1994 means only include August chlorophyll values. In 1988, fertilized reach values are inflated due to contamination by green algal filaments. Data are means \pm 1 SE.

Notes: Chlorophyll data in this figure reflect values that have been recalculated since estimates were published in the following manuscripts: Peterson et al. (1985, 1993a), Miller et al. (1992), Deegan et al. (1997). Due to an error (10×) in the conversion of the fluorometer readings, chlorophyll estimates presented in previously published manuscripts were too high, but the relative differences between reaches are not changed.

trus americanus densities were higher in the fertilized reach relative to the reference. Conversely, black fly (Simulidae) densities were consistently greater in the reference reach. Baetis spp. densities increased in the fertilized reach in the first four years of fertilization, but then declined in the fertilized reach relative to the reference from 1989 to 1998 . The density of the large mayfly, Ephemerella sp. increased dramatically in the fertilized reach in the 1990s. The densities of the tubebuilding chironomid, Orthocladius rivulorum, varied among years in both reaches and showed a variable response to $\mathrm{P}$ fertilization, especially prior to 1993 . The densities of other chironomids increased dramatically in the fertilized reach in the 1990s (Fig. 7).

\section{Fish}

There was high year-to-year variation of age-0 grayling masses and adult grayling growth rates in both the fertilized and reference reaches of the Kuparuk River. Mean 40-day weights of age-0 grayling were greater in the fertilized reach $(1.5 \pm 0.02 \mathrm{~g})$ than in the reference reach $(1.2 \pm 0.02 \mathrm{~g}$, paired $t$ test, $P=0.004$, $n=12$ years). Adult grayling growth rates were 1.2 $\pm 0.02 \mathrm{~g} / \mathrm{d}$ in the fertilized reach and $0.9 \pm 0.02 \mathrm{~g} / \mathrm{d}$ in the reference reach (paired $t$ test $P=0.048, n=11$ years); this $P$ value is not exact due to the presence of serial correlation in the adult fish growth data set for the fertilized reach only.

\section{DISCUSSION}

\section{Influence of mosses in the fertilized reach}

The major difference between the biological responses to 16 years of fertilization documented in this report and the biological responses of the Kuparuk River after the first four years described by Peterson et al. (1993a) was the increase in moss cover. Since 1992, the fertilized reach has undergone an almost 10-fold increase in bryophyte cover, the majority of this cover is the moss Hygrohypnum. Percent bryophyte coverage in the fertilized reach prior to the moss invasion was assumed to be the same as mean reference cover estimates of riffles $(\leq 5 \%)$. From 1992 to 1998, bryophytes covered $>50 \%$ of the area of the riffles in the fertilized reach. Visually, the contrast between 5 and $50 \%$ moss cover is the difference between a stream bottom of bare rock, where small tufts of the moss $S$. agassizii were almost unnoticeable, to a nearly continuous thick green carpet of filamentous Hygrohypnum. This dramatic shift in the composition of the dominant primary producers has impacted much of the biological system in the river.

TABLE 1. Standing stocks and atomic ratios of epilithic carbon, nitrogen, and phosphorus from reference and P-fertilized riffle rocks in the Kuparuk River, Alaska, during July and August (means with $1 \mathrm{SE}$ in parentheses; $n$ = years sampled).

\begin{tabular}{lccccccc}
\hline \hline & \multicolumn{3}{c}{ Standing stocks $\left(\mu \mathrm{mol} / \mathrm{cm}^{2}\right)$} & & \multicolumn{3}{c}{ Atomic ratios } \\
\cline { 2 - 3 } \cline { 7 - 8 } Riffle rocks & Carbon & Nitrogen & Phosphorus & & C:N & C:P & N:P \\
\hline Reference & $22.8(2.8)$ & $2.0(0.3)$ & $0.11(0.02)$ & & $12.2(0.7)$ & $232.2(27.4)$ & $20.3(2.7)$ \\
P-fertilized & $35.6(6.9)$ & $3.4(0.8)$ & $0.24(0.06)$ & & $11.6(0.8)$ & $153.8(16.9)$ & $14.1(1.8)$ \\
$n$ & 11 & 11 & 7 & & 11 & 7 & 7 \\
\hline
\end{tabular}




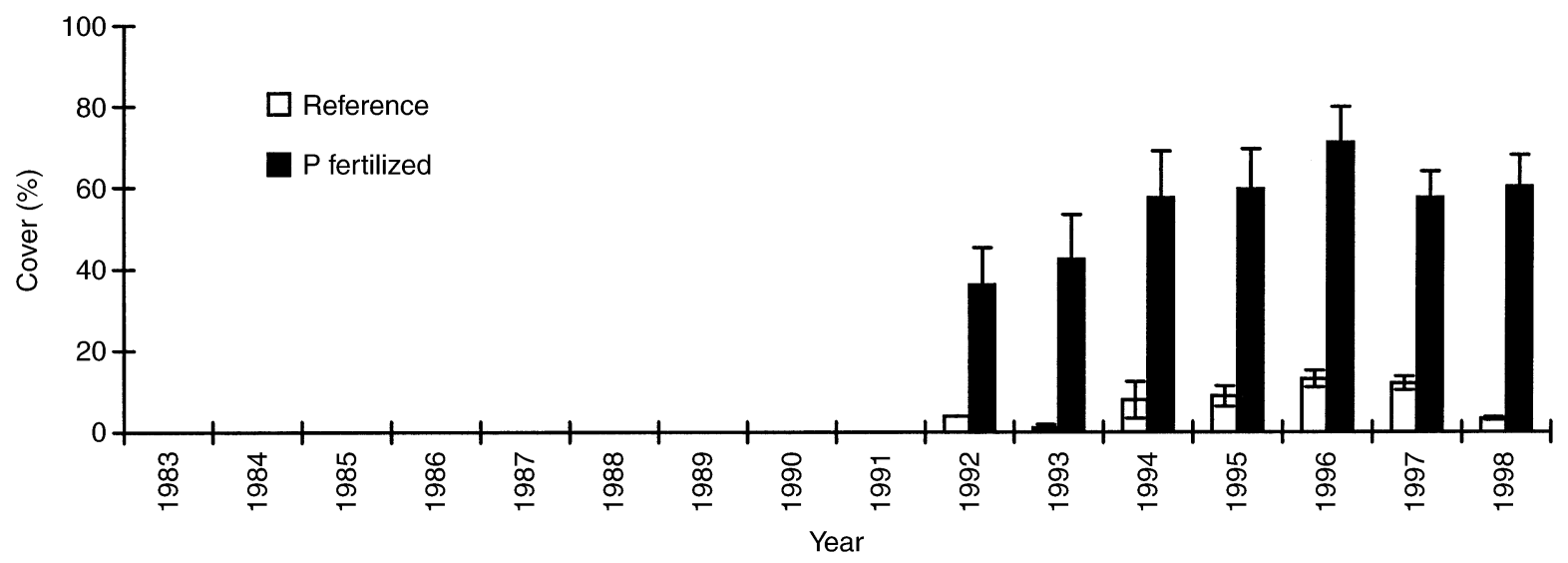

FIG. 6. Percentage of total bryophyte coverage (mean \pm 1 SE) in the Kuparuk River, 1992-1998.

Hygrohypnum not only replaced epilithic diatoms and other microalgae as the dominant primary producer, it also replaced $S$. agassizii as the dominant moss species in the fertilized reach. Arscott (1997) confirmed that $S$. agassizii has little physiological capacity to respond to increased nutrients, temperature, or light. In contrast, Hygrohypnum spp. has the capacity to grow much quicker when nutrients are abundant and temperature and light levels are high (Arscott 1997). S. agassizii and Hygrohypnum have very different morphology. S. agassizii has short, tufted fronds $<3 \mathrm{~cm}$ in length, even under fertilized conditions. Hygrohypnum, on the other hand, has long filamentous fronds that can extend over $20 \mathrm{~cm}$ in length, covering adjacent rocks that hold periphyton and other moss species.

As a result of this dramatic increase in moss cover in response to added $\mathrm{P}$, total stream NPP increased by almost three times; from $23 \mathrm{mg} \mathrm{C} \cdot \mathrm{m}^{-2} \cdot \mathrm{h}^{-1}$ to $63 \mathrm{mg}$ $\mathrm{C} \cdot \mathrm{m}^{-2} \cdot \mathrm{h}^{-1}$ (Arscott et al. 1998). Arscott (1997) estimated that $80 \%$ of the production in the fertilized reach is now driven by bryophytes and $20 \%$ by epilithic microalgae. Bryophytes only accounted for $9 \%$ of the

TABLe 2. Epiphytic and epilithic chlorophyll per $50 \mathrm{~m}^{2}$ in a reference $(0 \mathrm{~km})$ and $\mathrm{P}$-fertilized $(2 \mathrm{~km})$ riffle of the Kuparuk River (July 1998), Alaska, USA.

\begin{tabular}{|c|c|c|c|}
\hline Riffle & $\begin{array}{c}\text { Chlorophyll } \\
\left(\mathrm{mg} / \mathrm{m}^{2}\right. \\
\text { habitat })\end{array}$ & $\begin{array}{c}\text { Percent } \\
\text { cover, habitat }\end{array}$ & $\begin{array}{c}\text { Chlorophyll } \\
\text { (mg/riffle) }\end{array}$ \\
\hline \multicolumn{4}{|l|}{ Reference $(0 \mathrm{~km})$} \\
\hline $\begin{array}{l}\text { Rock } \\
\text { Hygrohypnum }\end{array}$ & & $\begin{array}{c}84.9(4.2) \\
0\end{array}$ & $\begin{array}{c}117.5(19.0) \\
\ldots\end{array}$ \\
\hline Schistidium & $3.2(0.9)$ & $3.3(0.9)$ & $5.2(1.4)$ \\
\hline \multicolumn{4}{|l|}{ Fertilized $(2 \mathrm{~km})$} \\
\hline Rock & $10.0(2.1)$ & $20.7(2.7)$ & $103.8(21.8)$ \\
\hline Hygrohypnum & $19.0(1.0)$ & $70.1(4.4)$ & $667.2(36.5)$ \\
\hline Schistidium & $6.1(1.4)$ & $5.4(0.7)$ & $16.5(3.8)$ \\
\hline
\end{tabular}

Notes: Chlorophyll estimates $\left(\mathrm{mg} / \mathrm{m}^{2}\right.$ riffle) are based on mean percent benthic coverage and the amount of chlorophyll per $\mathrm{m}^{2}$ of $100 \%$ moss or rock habitat from which the algal chlorophyll was measured. Standard errors of the means are in parenthesis, $n=3$. production in the reference reach. In addition, Arscott et al. (1998) found that the photosynthetic rates of $\mathrm{Hy}$ grohypnum (per unit area) in the Kuparuk River fertilized reach to be two- to four-fold greater than the epilithic algal productivity. This estimate is similar to the relative production of bryophytes and periphyton in boreal forest streams, where Naiman (1983) found annual moss production per unit area was about twice that of periphyton.

With this increase in primary production, we expected to see an increase in nutrient uptake. A ${ }^{15} \mathrm{~N}-$ $\mathrm{NH}_{4}$-tracer study found a marked increase in $\mathrm{NH}_{4}{ }^{+}$uptake in the fertilized reach of the Kuparuk River, where the areal uptake rate for $\mathrm{NH}_{4}{ }^{+}$was four times greater than in the reference reach (Wollheim et al. 2001). This was primarily due to Hygrohypnum's preference for $\mathrm{NH}_{4}{ }^{+}-\mathrm{N}$ over $\mathrm{NO}_{3}{ }^{-} \mathrm{N}$. The other less abundant moss, S. agassizii, preferred $\mathrm{NO}_{3}{ }^{-}-\mathrm{N}$ (Wollheim et al. 1999).

The major source of fine particulate organic matter (FPOM) in the reference reach of the Kuparuk River is peat eroded from the tundra (Peterson et al. 1986). Moss detritus may provide a more labile source of POM in the fertilized reach (Harvey et al. 1997, Lee and Hershey 2000). However, Lee and Hershey (2000) did not observe a change in the quantity of FPOM export between the reference and fertilized reaches of the $\mathrm{Ku}-$ paruk River. They found that changes in FPOM transport were more a function of discharge than stream reach. However, direct measurements of FPOM stocks in moss mats show that mosses trap larger amounts of FPOM than adjacent mineral substrates, thus increasing the amount of this food resource for benthic insects (Maurer and Brusven 1983, Suren and Winterbourn 1992, Stream Bryophyte Group 1999).

During the later years of the study, after the bryophytes replaced epilithic microalgae as the dominant cover in the fertilized reach, the moss biomass itself changed the benthic habitat structure. To illustrate the shift in benthic community composition, we calculated the ratio of mean moss period values (1992-1998) to 

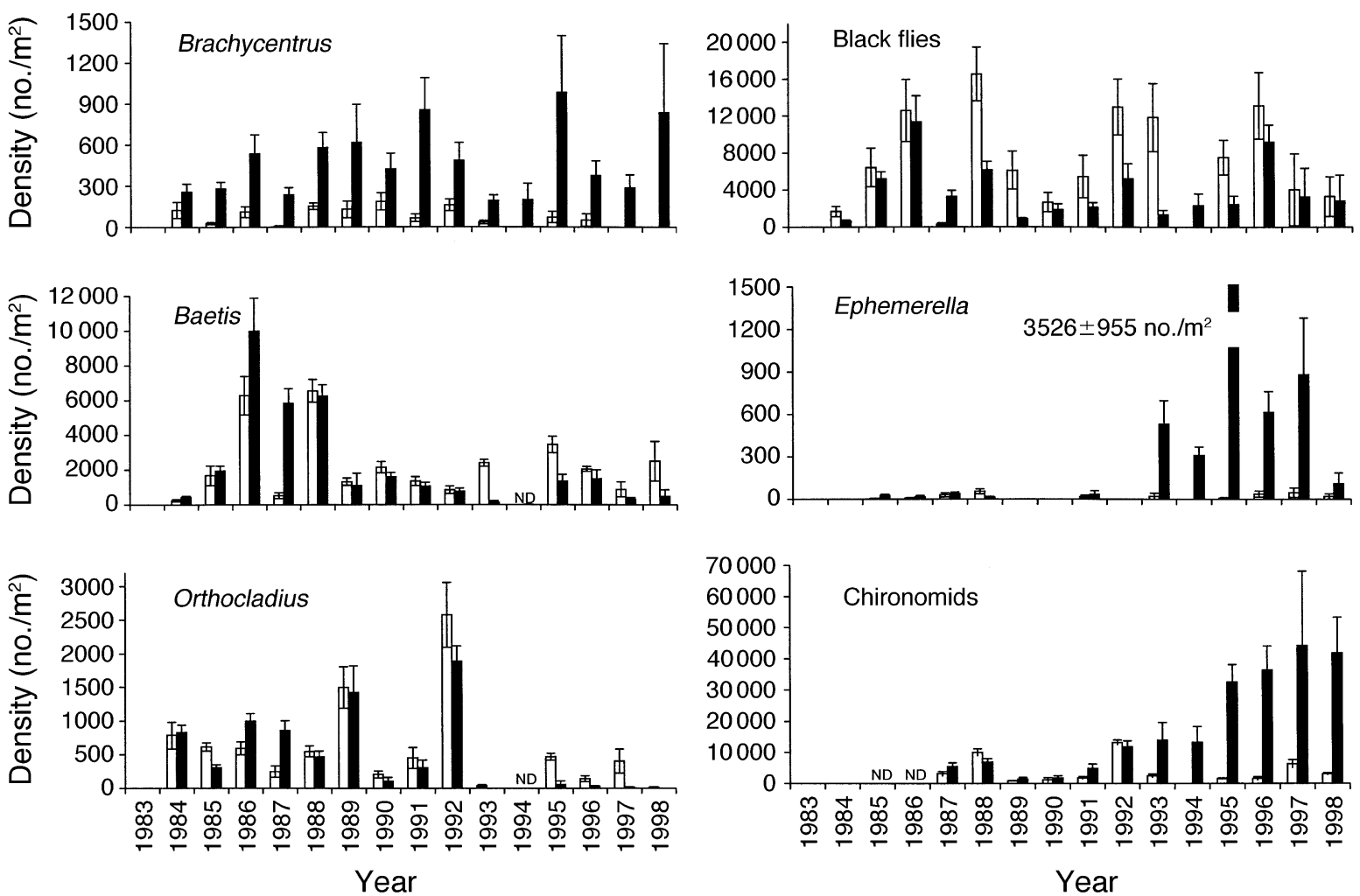

FIG. 7. Mean July densities of major benthic insect taxa in the reference (open bars) and fertilized (solid bars) reaches of the Kuparuk River, 1984-1998. Data were not available for 1983, the 1994 reference reach, and where "ND" appears.

pre-moss values (1983-1989) for the major parameters in both the reference and fertilized reach (Fig. 8A). The moss:pre-moss ratio is at or very close to one for biological parameters in the reference reach where moss had always been at low levels, indicating that no major changes in benthic community structure occurred in the reference reach from 1983-1989 to 1992-1998. The ratios in the fertilized reach indicate major positive and negative changes in the community composition, especially within the insect community.

However, it is important to separate the impact of moss on the stream community from the year-to-year variation due to impacts such as climate (discharge). This can be accomplished by calculating the ratio of the mean values for selected biological characteristics in the fertilized and reference reaches each year (i.e., $\left.X_{\text {fert }}: X_{\text {ref }}\right)$ for the periods (1983-1989 and 1992-1998); i.e., the periods before and after the moss became the dominant primary producer in the fertilized reach (Fig. $8 B)$. During the early years of the study, measurements of the major components of the Kuparuk River ecosystem show clear positive or negative responses to fertilization (Fig. 8B, open "pre-moss" bars), as described by Peterson et al. 1993a. In contrast, Fig. 8B illustrates the changes in the composition of the benthic community after $\sim 10$ years of phosphorus fertilization (solid "moss" bars). For example, during the pre-moss period, chironomid densities were about the same in the fertilized and reference reaches (fertilized to reference ratio $=1.4)$. After the moss became dominant (1992-1998), chironomid densities in the fertilized reach increased to an average fertilized:reference ratio of 11 .

A striking feature of the epilithic microalgal data is the distinct decline in epilithic chlorophyll stocks in the fertilized reach after 1991, coinciding with the increase in moss coverage. Epilithic chlorophyll in the fertilized reach was, on average, 3.6 times greater than reference levels during the years prior to the increase in moss coverage (1983-1989). After 1992, epilithic chlorophyll levels were only an average of 1.8 times higher in the fertilized reach (Fig. 8B). Epilithic production and percent coverage also declined in the fertilized reach after 1991, although not as dramatically. Along with the possible increase in grazing pressure proposed by Peterson et al. (1993a), we suggest two additional factors that may contribute to the decline in epilithic chlorophyll levels and production in the fertilized reach. First, there is physical disturbance from moss, which includes abrasion and light reduction by the long, Hygrohypnum fronds. Secondly, 1992-1997 were relatively high flow years, which may have led to an increase in scouring of the stream bottom under those higher current velocities.

Even though epilithic chlorophyll has declined and moss has replaced the epilithic algae as the dominant 

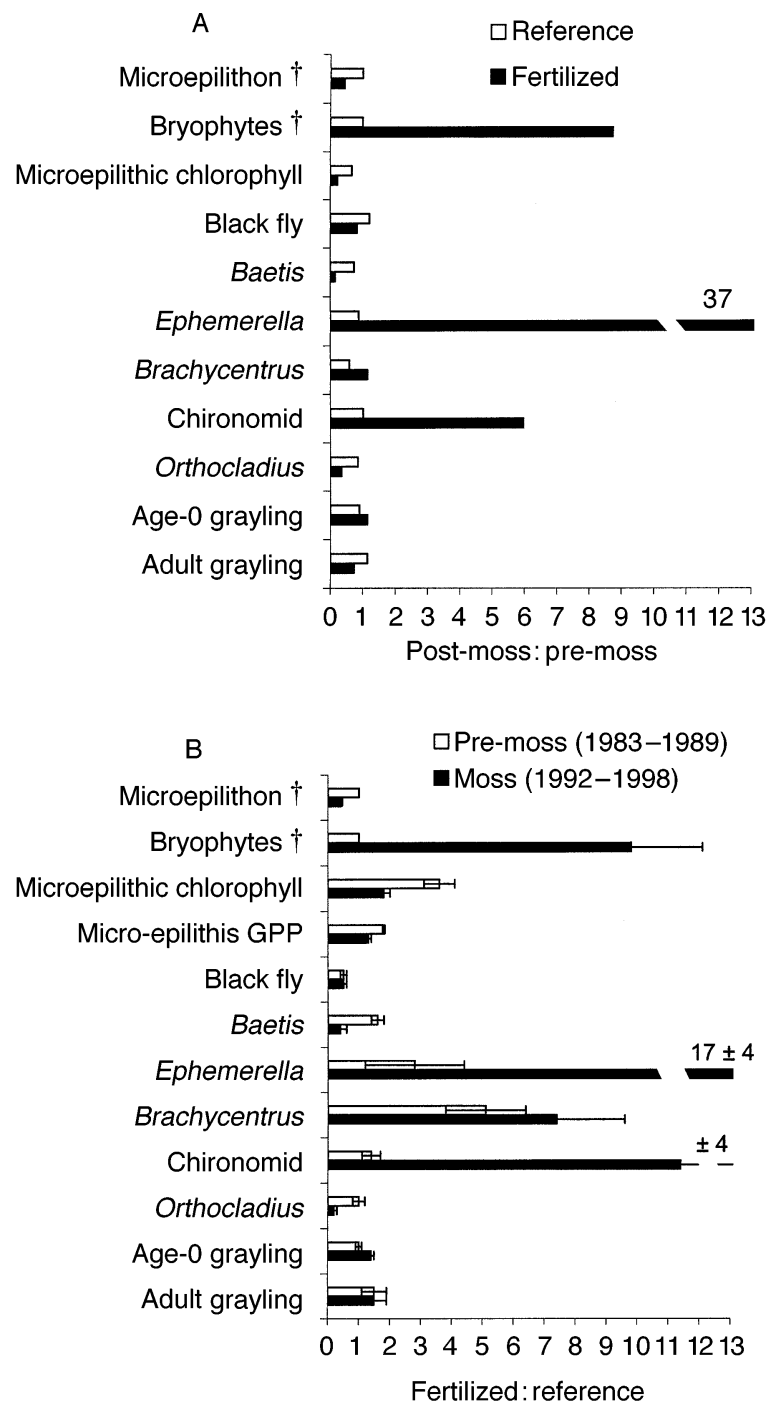

FIG. 8. Responses to phosphorus fertilization before and after the moss colonization of the Kuparuk River bottom. From top to bottom, the ratio values are of micro-epilithon and total bryophyte percent cover in riffles (\%), annual mean epilithic chlorophyll (micrograms per square centimeter), micro-epilithic gross primary production $\left(\mathrm{GPP}\left[\mathrm{mg} \mathrm{O}_{2} \cdot \mathrm{m}^{-2} \cdot \mathrm{h}^{-1}\right]\right.$; panel B only), benthic macroinvertebrate densities (no. $/ \mathrm{m}^{2}$ ), and adult (g/d) and age-0 grayling (g, 40-d mass) growth. (A) Responses are given as the mean ( $\pm 1 \mathrm{SE})$ of the annual ratios of fertilized and reference $\left(X_{\text {fertilixed }}: X_{\text {reference }}\right)$ values for each parameter. (B) Responses are given as the mean ( $\pm 1 \mathrm{SE}$ ) of the annual ratios of moss period (1992-1998) and pre-moss period (1983-1989) values for each parameter $\left(X_{\text {moss }}: X_{\text {pre-moss }}\right)$. Values marked with a dagger are parameters not measured prior to 1992 in the reference reach and are assumed to be the same in reference and fertilized reaches $(1: 1)$.

benthic cover, we have observed a net gain in total epiphyte plus epilithic algal chlorophyll in the fertilized reach. Moss provides more surface area per unit area stream bottom for algal colonization than does bare rock, and we found that epiphytic algal chlorophyll levels per square meter on Hygrohypnum were over five times greater than on adjacent rock substrate. These results are similar to those of Chantha et al. (2000), who found algal biomass per unit area stream bottom to be 10 times greater on moss than on adjacent rock substrate, thus providing more food resources for grazing insects. Because estimates of "moss production" include epiphytic diatoms, algal epiphytes are contributing to the higher primary production in the fertilized reach of the Kuparuk River.

It is difficult to determine how much of the differences in insect densities between reaches were due to $\mathrm{P}$ addition, changes in moss cover, or other unknown habitat features unique to each reach. Mean annual abundance was highly variable for all taxa, and some of the primary factors affecting the mean annual abundance of these taxa have been well documented in the Kuparuk. For example, Hershey et al. (1997) found that Brachycentrus and black fly abundance are associated with discharge. In addition, Hershey and Hiltner (1988) found that Brachycentrus negatively impacts black flies through predation or competition for space, resulting in lower black fly densities in the fertilized reach where Brachycentrus densities are relatively high.

Throughout the study, Brachycentrus densities were consistently higher in the fertilized reach and black fly densities were consistently lower in the fertilized reach relative to the reference reach. As with the other major taxa monitored in our study, we cannot demonstrate that densities were similar in the reference and fertilized reaches previous to 1983 and therefore differed in abundance of these taxa for reasons unrelated to fertilization. However, we have shown that the changes observed in the densities of some insect taxa (e.g., Ephemerella, chironomids, Orthocladius) in the reference reach were very small compared to the density changes that these same species exhibited in the fertilized reach between pre-moss and post-moss time periods (Fig. 8).

Long-term abundance estimates indicated substantial increases in chironomid and Ephemerella densities in the riffles of the fertilized reach only after the increase in moss coverage (Fig. 8). In comparisons of insect abundance on bare rock substrate vs. adjacent mosscovered rock in fertilized riffles of the Kuparuk River, chironomids, Ephemerella, and Brachycentrus were present in significantly higher densities on the bryophyte-dominated substrata (Stream Bryophyte Group 1999, Lee and Hershey 2000). Black flies showed no preference for either habitat in these studies. Moss substrate provides refuge and potential food sources such as epiphytic diatoms, FPOM trapped in the moss mats, and moss-derived coarse particulate organic metter (CPOM; Suren and Winterbourn 1992, see Stream Bryophyte Group 1999). Habitat preference studies suggest that the increase in habitat complexity and food resources (epiphytic algae and detritus) provided by the moss are responsible for the increase in the abundance of these taxa (Lee and Hershey 2000). There was 
TABLE 3. Food web response to long- and short-term nutrient enrichment in a variety of streams.

\begin{tabular}{|c|c|c|c|c|c|c|}
\hline Site & $\begin{array}{l}\text { Years } \\
\text { fertilized }\end{array}$ & $\begin{array}{l}\text { Nutrient } \\
\text { added }\end{array}$ & $\begin{array}{l}\text { Periphyton } \\
\text { (chlorophyll) }\end{array}$ & $\begin{array}{l}\text { Invertebrate } \\
\text { (density/ } \\
\text { biomass) }\end{array}$ & $\begin{array}{l}\text { Fish } \\
\text { (growth/ } \\
\text { density) }\end{array}$ & Reference \\
\hline \multicolumn{7}{|l|}{ Alaska, USA } \\
\hline Kuparuk River & 16 & $\mathrm{P}$ & + & $+1-$ & + & \\
\hline Kuparuk River & 4 & $\mathrm{P}, \mathrm{N}+\mathrm{P}$ & + & + & + & Peterson et al. (1993a) \\
\hline Oksrukuyik Creek & 4 & $\mathrm{~N}+\mathrm{P}$ & + & + & + & Harvey et al. (1998) \\
\hline \multicolumn{7}{|l|}{ Oregon, USA } \\
\hline Lookout Creek & 3 & $\mathrm{~N}$ & + & + & + & Gregory and Lamberti (1993) \\
\hline \multicolumn{7}{|c|}{ British Columbia, Canada } \\
\hline Keogh River & 4 & $\mathrm{~N}+\mathrm{P}$ & + & + & + & $\begin{array}{l}\text { Johnston et al. (1990), Perrin } \\
\text { et al. (1987) }\end{array}$ \\
\hline Salmon River & 3 & $\mathrm{~N}+\mathrm{P}$ & + & + & + & Slaney et al. (1994) \\
\hline Mesilinka River & 4 & $\mathrm{~N}+\mathrm{P}$ & + & + & + & $\begin{array}{l}\text { Slaney and Ashley (1998), } \\
\text { Koning et al. (1995), Paul } \\
\text { et al. (1996) }\end{array}$ \\
\hline Adam River & 4 & $\mathrm{~N}+\mathrm{P}$ & + & + & + & $\begin{array}{l}\text { Toth et al. (1997), Slaney } \\
\text { and Ashley (1998) }\end{array}$ \\
\hline Big Silver Creek & 2 & $\mathrm{~N}+\mathrm{P}$ & + & + & + & Toth et al. (1996) \\
\hline \multicolumn{7}{|l|}{ Tennessee, USA } \\
\hline Walker Branch & 95 days & $\mathrm{P}$ & + & + & NA & Elwood et al. (1981) \\
\hline
\end{tabular}

an overall decline in the abundance of Baetis and Orthocladius in both reaches and especially in the mossdominated fertilized riffles relative to reference riffles. The grazing mayfly, Baetis, did not show a preference for either rock or moss in the habitat comparison studies (Stream Bryophyte Group 1999, Lee and Hershey 2000). Densities of Orthocladius, the tube-building chironomid, were consistently lower in the fertilized reach relative to the reference reach after the increase in moss coverage. Orthocladius typically colonize bare rock substrate in the Kuparuk River (Hershey et al. 1988). If the increase in moss cover was responsible for their decline, it may likely be due to the loss of bare-rock substrate in the moss-dominated fertilized reach.

Although we cannot rule out other physical and biological factors, the results of our monitoring indicate that the presence of moss is the only obvious change in the fertilized reach habitat after 1992. Therefore, like the decrease in epilithic chlorophyll, we attribute the shifts in Ephemerella and chironomid densities in the fertilized reach mainly to the increase in moss cover. And although we observed a decline in Orthocladius and Baetis densities in the fertilized reach relative to the reference after 1992, additional study is needed to determine the mechanism behind those shifts and whether or not the increase in moss cover could have played a role.

Although the increase in moss cover has impacted the microalgae and the insect communities of the $\mathrm{Ku}$ paruk River, there were no measurable effects of increased moss coverage on the growth rates of either age- 0 or adult arctic grayling. The mean ratios of fertilized to reference reach growth both before and during the time of increased moss cover are identical for the adult grayling and very similar for age-0 grayling (Fig. 8B). Baetis and Brachycentrus are thought to be the most important prey items for adult grayling (Peterson et al. 1993b, Hershey et al. 1997). While Baetis abundance was variable, Brachycentrus densities remained relatively high in the fertilized reach. In addition, the abundance of the large mayfly Ephemerella also steadily increased in the fertilized reach. Thus far, mossinduced changes in the lower trophic levels have had no apparent effect on the fish growth. However, if moss inhibits insect drift, the availability of insects may decline and the yield of fish per gram of insect production may be reduced. Further study is needed to determine if this will happen.

\section{Comparisons to other long-term fertilization studies}

Nutrient enrichment studies of arctic and temperate rivers have shown increases in primary and secondary production with the addition of limiting nutrients ( $\mathrm{N}$ and/or P; Table 3). Yet the conclusions drawn from many short-term (1-4-year) stream fertilization studies and the 16-year Kuparuk River study are very different. For example, like other stream fertilization studies (e.g., Rosemond et al. 1993, Anderson et al. 1999, and others), epilithic algae in the fertilized reach of the Kuparuk River was first limited by low nutrient concentrations and then by grazing pressure from an increase in invertebrate grazers. However, in the Kuparuk River, this response was only apparent during the first few years of our study (Peterson et al. 1993a). After eight to ten years, moss has replaced epilithic algae as the dominant benthic cover in the fertilized riffles. Now epilithic algae appear to be space limited though competition from moss. In addition, the response of insects to fertilization was not the same for all taxa in the latter 
years of the study. For example, while relative trends in densities of Brachycentrus and black flies remained similar throughout the 16-year study, Baetis and Orthocladius did not exhibit sustained increased densities in the fertilized reach after the first five years of the study.

Slaney and Ashley (1998) have summarized wholestream fertilization studies of oligotrophic streams in British Columbia. The focus of those studies was to understand the effects of nutrient enrichment on productivity, with the goal of enhancing stream fish abundance and growth. And like these studies in British Columbia, we attribute the increase in fish growth rates to the increased abundance and growth of insects in the fertilized reach (Hershey et al. 1988, Deegan and Peterson 1992). However, this long-term data set revealed that fluctuations in discharge and temperature explained much of the annual variability in growth and the magnitude of grayling response (Deegan et al. 1999). The results of these whole-stream fertilization studies are generally consistent with the first several years of the Kuparuk River study, where an increase in production was documented in some species at all trophic levels (Table 3). Nonetheless, it would be a mistake to assume that streams on the North Slope would all respond in a manner similar to these three tundra streams. In particular, mountain, glacial, and spring streams are likely to have very different controls on productivity and trophic structure (Craig and McCart 1975).

\section{Conclusions}

In the Kuparuk River, the impact of fertilization was more complex than a positive increase in production from one trophic level to the next. We show how the ecosystem structure of a tundra stream changed over time in response to nutrient enrichment. This observation emphasizes the need for long-term, wholestream studies if we expect to predict stream response to chronic perturbation.

There was a substantial biological response to phosphorus fertilization in the Kuparuk River. It is predicted that global climate change will likely cause a release of phosphorus into streams from melting permafrost (Hobbie et al. 1999). This long-term fertilization study suggests that ecosystem structure of nutrient limited tundra streams will change, production will increase, and the stream community composition will probably change if increased nutrient loading is sustained for many years. Shorter term spikes in nutrient loading will increase productivity but cause much less change in community structure.

The effects of the dramatic rise in moss have been felt throughout the stream ecosystem. Hygrohypnum changed many factors including $\mathrm{NH}_{4}{ }^{+}$uptake rates, epilithic chlorophyll stocks, primary production, habitat structure, and insect abundance and species composition. It is also likely that the moss increase led to chang- es in FBOM storage, autochthonous detritus production, and microbial activity. Thus far, there have been no discernable effects on fish growth rates as a result of the moss-driven changes in the insect community.

Additional long-term whole stream fertilization studies are needed to better understand the delayed stream ecosystem responses to nutrient enrichment. Even studies of two to eight years in duration may be poor predictors of the long-term responses to added nutrients. It is clear that in order to predict the long-term consequences of global climate change and disturbance for stream ecosystems, we must understand both the rapid and the delayed responses to perturbation.

\section{ACKNOWLEDGMENTS}

This research was supported by National Science Foundation grants OPP-9911278 and DEB-9810222 in conjunction with the Long-Term Ecological Research Program. The authors gratefully thank the numerous colleagues, research assistants, graduate and undergraduate students for their contribution to the Kuparuk River study, especially Mike Miller, Dave Arscott, Jacques Finlay, Ken Edwardson, Jim Lee, Carolyn Bauman, Chris Harvey, John Helfrich, Heidi Golden, Alison Hiltner, Karen Buzby, and George Kling. We thank Doug Kane and Rob Gieck of UAF for their assistance with the Kuparuk River hydrological data. We also thank the staff of the Toolik Lake Field Station for their logistical support.

\section{Literature Cited}

Abelson, P. H. 1989. The arctic: a key to world climate. Science 243:873.

Anderson, E. L., E. B. Welch, J. M. Jacoby, G. M. Schimek, and R. R. Horner. 1999. Periphyton removal related to phosphorus and grazer biomass level. Freshwater Biology 41:633-651.

Arscott, D. B. 1997. Primary production in a 4th order arctic stream. Thesis. University of New Hampshire, Durham, New Hampshire, USA.

Arscott, D. B., W. B. Bowden, and J. C. Finlay. 1998. Comparison of epilithic algal and bryophyte metabolism in an arctic tundra stream, Alaska. Journal of the North American Benthological Society 17:210-227.

Bowden, W. B., J. C. Finlay, and P. E. Maloney. 1994. Longterm effects of $\mathrm{PO}_{4}$ fertilization on the distribution of bryophytes in an arctic river. Freshwater Biology 32:445-454.

Bowden, W. B., B. J. Peterson, J. C. Finlay, and J. Tucker. 1992. Epilithic chlorophyll $a$, photosynthesis, and respiration in control and fertilized reaches of a tundra stream. Hydrobiologia 240:121-131.

Carpenter, S. R. 1989. Replication and treatment strength in whole-lake experiments. Ecology 70:453-463.

Chantha, S. C., L. Cloutier, and A. Cattaneo. 2000. Epiphytic algae and invertebrates on aquatic mosses in a Quebec stream. Archiv fuer Hydrobiologie 147:143-160.

Chapin, F. S., III, G. R. Shaver, A. E. Giblin, K. J. Nadelhoffer, J. A. Laundre. 1995. Responses of arctic tundra to experimental and observed changes in climate. Ecology 76:694711.

Chapman, W. L., and J. E. Walsh. 1993. Recent variations of sea ice and air temperatures in high arctic latitudes. Bulletin of the American Meteorological Society 74:3347.

Craig, P. C., and P. J. McCart. 1975. Classification of stream types in Beaufort Sea drainages between Prudhoe Bay, Alaska and the MacKenzie Delta, NWT. Arctic and Alpine Research 7:183-198.

Deegan, L. A., H. E. Golden, C. J. Harvey, and B. J. Peterson. 1999. Influence of environmental variability on the growth 
of age- 0 and adult arctic grayling. Transactions of the American Fisheries Society 128:1163-1175.

Deegan, L. A., and B. J. Peterson. 1992. Whole-river fertilization stimulates fish production in an arctic tundra river. Canadian Journal of Fisheries and Aquatic Sciences 49: 1890-1901.

Deegan, L. A., B. J. Peterson, H. Golden, C. C. McIvor, and M. C. Miller. 1997. Effects of fish density and river fertilization on algal standing stocks, invertebrate communities, and fish production in an arctic river. Canadian Journal of Fisheries and Aquatic Sciences 54:269-283.

Elwood, J. W., J. D. Newbold, A. F. Trimble, and R. W. Stark. 1981. The limiting role of phosphorus in a woodland stream ecosystem: effects of $\mathrm{P}$ enrichment on leaf decomposition and primary producers. Ecology 62:146-158.

Gettel, G. M., and L. A. Deegan. 1997. A comparison of whole and thin-sectioned aging techniques and validation of annuli for Arctic grayling. Northwest Science 71:224232.

Gregory, S. V., and G. A. Lamberti. 1993. Trophic responses to nutrient addition in a fifth-order mountain stream. North American Benthological Society Abstracts Bulletin, Spring:105.

Harvey, C. J., B. J. Peterson, W. B. Bowden, L. A. Deegan, J. C. Finlay, A. E. Hershey, and M. C. Miller. 1997. Organic matter dynamics in the Kuparuk River, a tundra river in Alaska. Journal of the North American Benthological Society 16:18-22.

Harvey, C. J., B. J. Peterson, W. B. Bowden, A. E. Hershey, M. C. Miller, L. A. Deegan, and J. C. Finlay. 1998. Biological responses to fertilization of Oksrukuyik Creek, a tundra stream. Journal of the North American Benthological Society 17:190-209.

Hershey, A. E., et al. 1997. The Kuparuk River: a long-term study of biological and chemical processes in an arctic river. Pages 107-129 in A. M. Milner and M. W. Oswood, editors. Freshwaters of Alaska. Springer-Verlag, New York, New York, USA.

Hershey, A. E., and A. L. Hiltner. 1988. Effect of a caddisfly on black fly density: interspecific interactions limit black flies in an arctic river. Journal of the North American Benthological Society 7:188-196.

Hershey, A. E., A. L. Hiltner, M. A. J. Hullar, M. C. Miller, J. R. Vestal, M. A. Lock, S. Rundle, and B. J. Peterson. 1988. Nutrient influence on a stream grazer: Orthocladius microcommunities respond to nutrient input. Ecology 69 : 1383-1392.

Hiltner, A. L. 1985. Response of the black fly species (Diptera: Simuliidae) to phosphorus enrichment of an arctic tundra stream. Thesis. University of Wisconsin, Madison, Wisconsin, USA.

Hobbie, J. E., B. J. Peterson, N. Bettez, L. Deegan, W. J. O'Brien, G. W. Kling, G. W. Kipphut, W. B. Bowden, and A. E. Hershey. 1999. Impact of global climate change on the biogeochemistry and ecology of an Arctic freshwater system. Polar Research 18(2):207-214.

Hurlbert, S. H. 1984. Pseudoreplication and the design of ecological field experiments. Ecological Monographs 54: $187-211$

Johnston, N. T., C. J. Perrin, P. A. Slaney, and B. R. Ward. 1990. Increased juvenile growth by whole-river fertilization. Canadian Journal of Fisheries and Aquatic Sciences 47:862-872.

Kane, D. L., L. D. Hinzman, C. S. Benson, and K. R. Everett. 1989. Hydrology of Imnavait Creek, and arctic watershed. Holarctic Ecology 12:262-269.

Kane, D. L., L. D. Hinzman, M. Woo, and K. R. Everett. 1992. Arctic hydrology and climate change. Pages 35-58 in F. S. Chapin, R. L. Jefferies, J. F. Reynolds, G. R. Shaver, and J. Svodboda, editors. Arctic ecosystems in a changing climate: an ecophysiological perspective. Academic Press, San Diego, California, USA.

Koning, C. W., K. I. Ashley, P. A. Slaney, R. W. Land, and P. W. Davidson. 1995. Development of a premier northern river fishery: Mesilinka River pre-fertilization progress 1992-1993. Fisheries Progress Report Number RD 46. Ministry of the Environment, Lands and Parks, Victoria, British Columbia, Canada.

Kriet, K., B. J. Peterson, and T. L. Corliss. 1992. Water and sediment export of the upper Kuparuk River drainage of the North Slope of Alaska. Hydrobiologia 240:71-81.

Lachenbruch, A. H., and B. V. Marshall. 1986. Changing climate: geothermal evidence from permafrost in the Alaskan arctic. Science 234:689-696.

Lee, J. O., and A. E. Hershey. 2000. Effects of aquatic bryophytes and long-term fertilization on arctic stream insects. Journal of the North American Benthological Society 19: 697-708.

Maurer, M. A., and M. A. Brusven. 1983. Insect abundance and colonization rate in Fontinalis neo-mexicana (Bryophyta) in an Idaho Batholith stream, USA. Hydrobiologia 98:9-15.

McNamara, J. P., D. L. Kane, and L. D. Hinzman. 1997. Hydrograph separations in an Arctic watershed using mixing model and graphical techniques. Water Resources Research 33:1707-1719.

Miller, M. C., P. DeOliveira, and G. G. Gibeau. 1992. Epilithic diatom community response to years of $\mathrm{PO}_{4}$ fertilization: Kuparuk River, Alaska (68 N Lat.). Hydrobiologia 240:103-119.

Murphy, J., and G. Riley. 1962. A modified single solution method for the determination of phosphate in natural waters. Analytica Chimica Acta 27:31-36.

Nadelhoffer, K. J., A. E. Giblin, G. R. Shaver, and A. E. Linkins. 1992. Microbial processes and plant nutrient availability in arctic soils. Pages 281-300 in F. S. Chapin, R. L. Jefferies, J. F. Reynolds, G. R. Shaver, and J. Svodboda, editors. Arctic ecosystems in a changing climate: an ecophysiological perspective. Academic Press, San Diego, California, USA.

Naiman, R. J. 1983. The annual pattern and spatial distribution of aquatic oxygen metabolism in boreal forest watersheds. Ecological Monographs 53:73-94.

Paul, A. J., C. W. Koning, K. I. Ashley, P. A. Ashley, P. W. Davidson, and R. W. Land. 1996. Development of a premier northern river fishery: Mesilinka River, the first year of fertilization (1994). Fisheries Progress Report Number RD 50. Ministry of the Environment, Lands and Parks, Victoria, British Columbia, Canada.

Perrin, C. J., M. L. Bothwell, and P. A. Slaney. 1987. Experimental enrichment of a coastal stream in British Columbia: effects of organic and inorganic additions on autotrophic periphyton production. Canadian Journal of Fisheries and Aquatic Sciences 44:1247-1256.

Peterson, B. J., T. Corlis, K. Kriet, J. E. Hobbie. 1992. Nitrogen and phosphorus concentrations and export for the upper Kuparuk River on the North Slope of Alaska in 1980. Hydrobiologia 240:61-69.

Peterson, B. J., et al. 1993a. Biological responses of a tundra river to fertilization. Ecology 74:653-672.

Peterson, B. J., B. Fry, L. Deegan, A. E. Hershey. $1993 b$. The trophic significance of epilithic algal production in a fertilized tundra river ecosystem. Limnology and Oceanography 38:872-878.

Peterson, B. J., J. E. Hobbie, and T. L. Corliss. 1986. Carbon flow in a tundra stream ecosystem. Canadian Journal of Fisheries and Aquatic Sciences 43:1259-1270.

Peterson, B. J., J. E. Hobbie, A. E. Hershey, M. A. Lock, T. E. Ford, J. R. Vestal, V. L. McKinley, M. A. Hullar, M. C. Miller, R. M. Ventullo, and S. S. Volk. 1985. Transfor- 
mation of a tundra river from heterotrophy to autotrophy by addition of phosphorus. Science 229:1383-1386.

Pindyck, R. S., and D. L. Rubinfeld. 1998. Econometric models and economic forecasts. Irwin/McGraw-Hill, Boston, Massachusetts, USA.

Ricker, W. E. 1979. Growth rates and models. Pages $677-$ 734 in W. S. Hoar and J. E. Brett, editors. Fish physiology. Volume 8. Bioenergetics and growth. Academic Press, New York, New York, USA.

Rosemond, A. D., P. J. Mulholland, and J. W. Elwood. 1993. Top-down and bottom-up control of stream periphyton: effects of nutrients and herbivores. Ecology 74:1264-1280.

Rouse, W. R., M. Douglas, R. E. Hecky, A. Hershey, G. W. Kling, L. Lesack, M. M. P. Marsh, B. Nicholson, N. Roulet, and J. Smol. 1997. Effects of climate change on the fresh waters of arctic and subarctic North America. Hydrological Processes 11:873-902.

SAS. 1987. Version 6. SAS Institute, Cary, North Carolina, USA.

Slaney, P. A., and K. I. Ashley. 1998. Case studies of wholestream fertilization in British Columbia. Pages 83-97 in J. G. Stockner and G. Milbrink, editors. Restoration of fisheries by enrichment of aquatic ecosystems. Uppsala University, Uppsala, Sweden.

Slaney, P. A., K. Ashley, C. Wightman, R. Ptolemy, and D. Zaldakos. 1994. Low-level fertilization as a habitat management option for nutrient deficient trout streams in British Columbia. Pages 1-23 in the Proceedings of the 9th International Trout Stream Habitat Improvement Workshop. Trout Unlimited Canada, Calgary, Alberta, Canada.

Smith, V. H., G. D. Tilman, and J. C. Nekola. 1999. Eutrophication: impacts of excess nutrient inputs on freshwater, marine, and terrestrial ecosystems. Environmental Pollution 100:179-196.

Solorzano, L. 1969. Determination of ammonia in natural waters by the phenolhypochlorite method. Limnology and Oceanography 14:799-801.

Stainton, M. P., M. J. Capel, and F. A. J. Armstrong. 1977. The chemical analysis of fresh water. Second edition. Canadian Fisheries and Marine Service Miscellaneous Special Publication 25. Ministry of the Environment, Lands and Parks, Victoria, British Columbia, Canada.
Steele, R. G. D., and J. H. Torrie. 1980. Principles and procedures of statistics. McGraw-Hill, New York, New York, USA.

Stewart-Oaten, A., and J. R. Bence. 2001. Temporal and spatial variation in environmental impact assessment. Ecological Monographs 71:305-339.

Stream Bryophyte Group. 1999. Roles of bryophytes in stream ecosystems. Journal of the North American Benthological Society 18:151-184.

Strickland, J. D. H., and T. R. Parsons. 1968. A manual of seawater analysis. Second edition. Bulletin of the Fisheries Research Board of Canada 125. Ministry of the Environment, Lands and Parks, Victoria, British Columbia, Canada.

Suren, A. M., and M. J. Winterbourn. 1992. The influence of periphyton, detritus and shelter on invertebrate colonization of aquatic bryophytes. Freshwater Biology 27:327339.

Toth, B. M., K. I. Ashley, G. A. Wilson, C. W. Koning, P. A. Slaney, and R. W. Land. 1996. Development of premier river fishery: Big Silver Creek fertilization experiment, year two (1995) of low-level inorganic nutrient addition. Fisheries Progress Report Number RD 56. Ministry of the Environment, Lands and Parks, Victoria, British Columbia, Canada.

Toth, B. M., K. I. Ashley, G. A. Wilson, C. W. Koning, P. A. Slaney, D. Rimmer, and R. W. Land. 1997. Development of a resident trout fishery on the Adam River through increased habitat productivity: year two (1995) of low-level nutrient addition. Fisheries Progress Report Number RD 57. Ministry of the Environment, Lands and Parks, Victoria, British Columbia, Canada.

Wollheim, W. M., B. J. Peterson, L. A. Deegan, M. Bahr, J. E. Hobbie, D. Jones, A. E. Hershey, G. W. Kling, and M. C. Miller. 1999. A coupled field and modeling approach for the analysis of nitrogen cycling in streams. Journal of the North American Benthological Society 18:199-221.

Wollheim, W. M., B. J. Peterson, L. A. Deegan, J. E. Hobbie, B. Hooker, W. B. Bowden, K. J. Edwardson, D. B. Arscott, A. E. Hershey, and J. Finlay. 2001. Influence of stream size on ammonium and suspended particulate nitrogen processing. Limnology and Oceanography 46:1-13.

Woo, M. K., A. G. Lewkowicz, and W. R. Rouse. 1992. Response of the Canadian permafrost environment to climate change. Physical Geography 13(4):287-317. 